\title{
Histopathological changes in the gill architecture of Labeo rohita from the pond adjacent to thermal power station, K oradi, Nagpur, India
}

\author{
A. S. Deshpande ${ }^{1}$, S. B. Zade*1 and S. R. Sitre ${ }^{2}$ \\ ${ }^{1}$ Department of Zoology, RTM Nagpur University Campus, Nagpur- 440033 (M.S.), INDIA \\ ${ }^{2}$ N.S. Science \& Arts College Bhadrawati, Dist. Chandrapur- 442902 (M.S.), INDIA \\ *Corresponding author. E-mail: profsbzade@ rediffmail.com
}

\begin{abstract}
The hazardous effect of water pollution on the histopathology of selected organs of the freshwater fish Labeo rohita was studied with respect to thermal power plant effluent. The purpose of this research paper is to study whether the thermal plume can affect fish assemblages in the waters around the outlet area of the thermal power plant located at Koradi near Nagpur city. Both experimental and control fishes were monitored for a year from March 2010 to Feb. 2011. Histopathology serve as a tool to assess the extent of damage caused to the organism. Gill tissue showed fusion of primary lamellae, congestion of blood vessels and hyperplasia of bronchial plates. The histopathological changes in the gill tissue include epithelial hyperplasia, curling of secondary lamellae and changes in chloride cells. Besides these changes pyknotic nuclei, vacuolization, degradation of epithelial and pillar cells, were noticed, which point out towards deleterious effect of thermal power plant effluent on the freshwater fish L. rohita.
\end{abstract}

Keywords: Histopathological changes, Labeo rohita, Gill, Thermal power plant effluent

\section{INTRODUCTION}

Over the last few decades, contamination of aquatic ecosystems has attracted the attention of several investigators both in the developed and developing nations of the world. Many industrial and agricultural processes have contributed to the contamination of fresh water systems thereby causing adverse effect on aquatic biota and on human health (Wang, 2002; Dautremepuits et al., 2004). The varied pollutants from the industries disturb the aquatic environment too and leads to environmental health hazards (Shukla et al., 2007; Gupta and Srivastava, 2006; Agtas et al., 2007; Yoon etal., 2008). The fact that heavy metals can not be destroyed through biological degradation and have ability to accumulate in the environment makes these toxicants deleterious to the aquatic environment and consequently to man who depends upon aquatic products as food.

Heavy metals can accumulate in the tissues of aquatic animals and as such tissue concentrations of heavy metals can be of public health concerns to both animals and man (Kalay et al., 1999; Ashraf, 2005). Fishes are largely being used for the assessment of the health of aquatic environment and can serve as bioindicators of environmental pollution. (Dautremepuits et al., 2004). Fishes are very susceptible to bioaccumulation in their tissues as they take up residues of contaminants from the water through the gills and skin (Ortiz et al., 2002). Labeo rohita is one of the Indian major carp that dominates freshwater aquaculture in India. As fish is staple food for human and prey for carnivores, it is a component of food chain (Deichmann et al., 1975). Till date very scanty work was undertaken on fishes present in thermal power plant effluent. In this context, an attempt was made to observe the histopathological alterations in the gill of $L$. rohita from pond in the vicinity of thermal power plant of Nagpur city.

\section{MATERIALS AND METHODS}

Healthy L r rohita were procured from the pond of Koradi situated adjacent to thermal power station (KTPS), situated in Nagpur district. Fish measuring about 50-60 $\mathrm{cm}$ in length and about $500 \mathrm{gm}$ in weight are caught and used for experimentation purpose. The L. rohita was dissected and the gill tissues were removed and fixed in bovin's fixative and then processed for microtome sectioning at 5 micron, stained with $\mathrm{HE}$ and mounted in DPX. Subsequently the tissues were examined and microphotographs were taken.

\section{RESULTS AND DISCUSSION}

The gills are one of the most delicate structures of a teleost. They directly come in contact with the medium i.e. water. Thus, they are vulnerable and liable to be damaged by any irritant material, which may be dissolved or suspended in water. Histologically, the gills comprise of epithelium, endothelium, pillar cells, fibrous and cartilaginous support stroma in primary lamellae and 

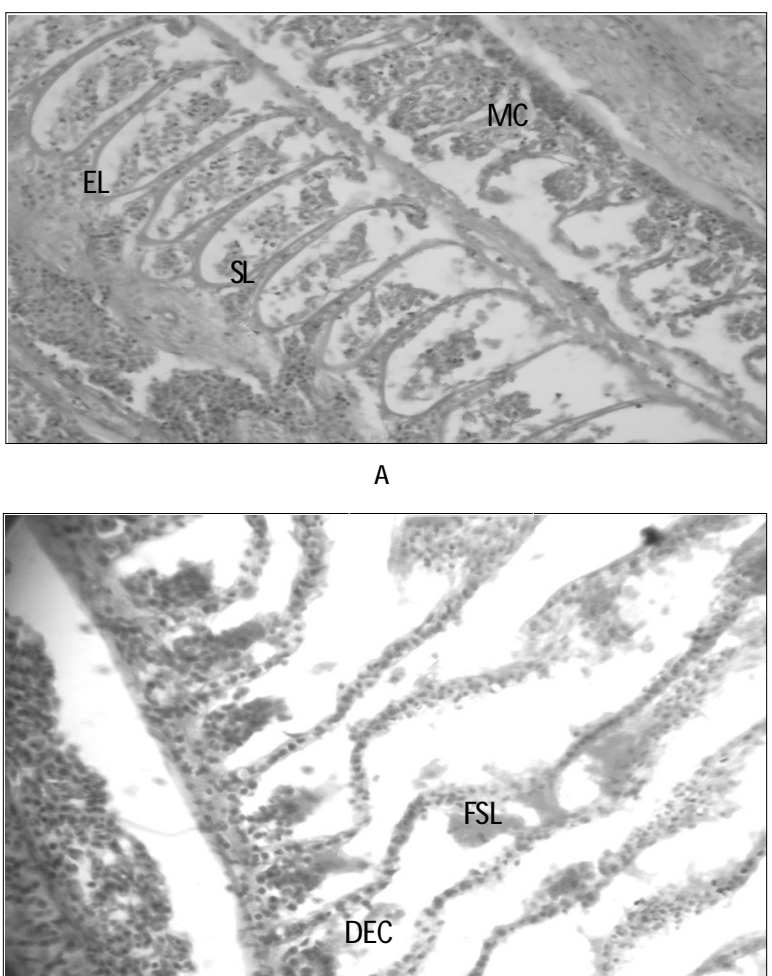

C
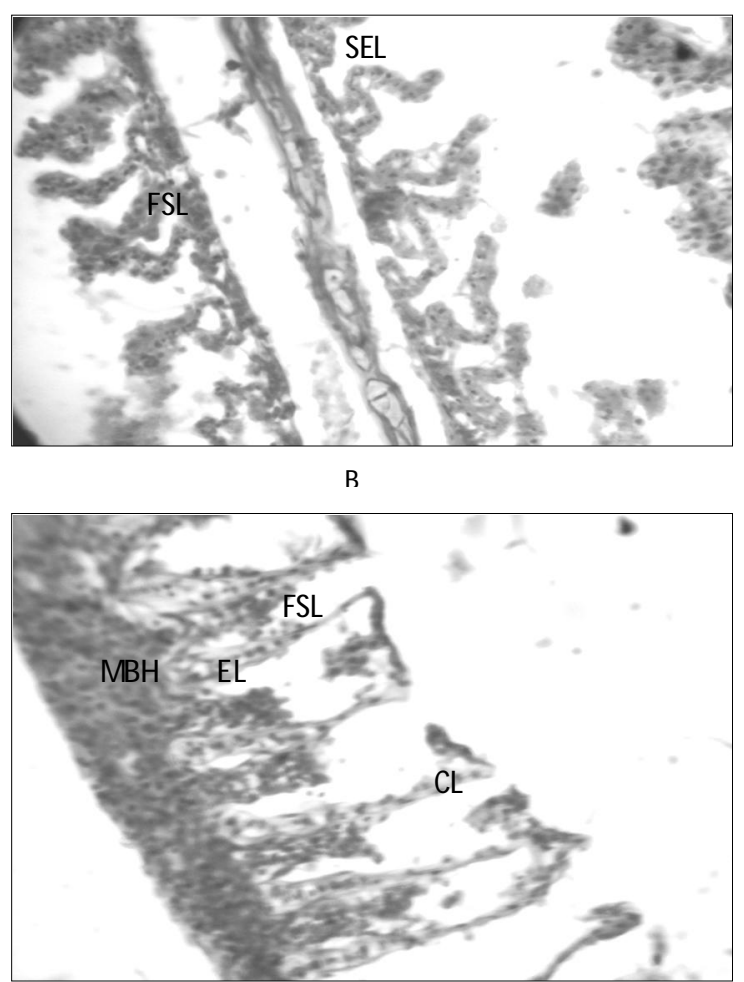

D

Fig.1. T. S. of L. rohita illustrating: A.: The normal structure showing secondary gill lamellae (SL) with epithelial lining (EL), mucus cells (MC). B and C: C hanges in fish exposed to polluted water evidenced by shrinkage of epithelial lining (SEL), bending and thickening of the epithelial tissue at the pick of the lamellae giving appear ance of a club (CT), fusion of secondary lamellae (FSL) and moderate basal hyperplasia (M BH), disruption of epithelial cells (DEC) and secretion of mucus, fusion of two or more lamellae (FSL) and shortening of secondary lamellae, epithelial lifting (EL). All the preparation in Ehrlich's Haematoxyline-E osin preparation X 400. D: M odrate basal hyperplasia, mucus cell proliferation, curling of secondary lamellae.

specialized cells like mucous cells, salt cells, eosinophil, granule cells and fixed macrophages (Fig.1).

The histopathological alterations in the gills of L. rohita from pond of Koradi during summer season includes focal areas of proliferation in the epithelium of gill filaments and secondary lamellae, resulting in fusion of secondary lamellae, severe degenerative and necrotic changes in gill filaments, curling of secondary lamellae and mucous cells proliferation (Fig.1). Edematous changes, characterized by epithelial detachment, were observed in gill filaments and secondary lamellae. Moreover, aggregations of inflammatory cells were noticed in gill filaments. Also, dilation and congestion in blood vessels of gill filaments were observed.

The gills, which participate in many important functions in the fish, such as respiration, osmoregulation and excretion, remain in close contact with the external environment and are particularly sensitive to changes in the quality of the water and are considered the primary target of the contaminants (Camargo and Martinez, 2007; Fernandes and Mazon, 2003).

In the present investigation gills of studied fish showed degenerative, necrotic and proliferative changes in gill filaments and secondary lamellae, edema in gill filaments and secondary lamellae and congestion in blood vessels of gill filaments. These pathological changes may be a reaction to toxicants intake like presence of heavy metals in the effluent and adaptive response to prevent the entry of pollutants through the gill surface.

The observed alterations like proliferation of the epithelial cells, partial fusion of some secondary lamellae and epithelial lifting are defense mechanisms. Since, in general, these result in the increase of the distance between the external environment and the blood and thus serve as a barrier to the entrance of contaminants (Fernandes and Mazon, 2003; Poleksic and Mitrovic-Tutundzic, 1994). The cellular damage observed in the gills in terms of epithelial proliferation, separation of the epithelial layer from supportive tissues and necrosis can adversely affect the gas exchange and ionic regulation. The observed edematous change in gill filaments and secondary lamellae are probably due to increased capillary permeability (Olurin et al., 2006).

The present results are in agreement with those observed in other fish species under the influence of different pollutants (Kakuta and Murachi, 1997; Olurin et al., 2006). In this respect, Camargo and Martinez (2007) observed hyperplasia of the epithelial cells, fusion of 
secondary lamellae, lifting of the lamellar epithelium and blood congestion in the gills of $P$. lineatus caged in Cambé stream, Brazil, polluted by industrial, domestic and agricultural wastes. Triebskorn et al. (2008) noticed epithelial lifting, proliferation of epithelial cells of primary and secondary lamellae, hyperplasia of mucous cells and necrosis of epithelial cells in the gills of $C$. nasus and $L$. cephalus from River Mures, Western Romania, polluted by heavy metals, faecal coliforms and streptococci. It could be concluded that, the polluted water of Koradi lake induced several histopathological alterations in the gills of L. rohita. Consequently, it is recommended to coordinate different efforts to rescue pond from the water pollution problems. The overcoming of these problems can be possible by subjecting the drainage waters discharged into the lake to technical treatments that fulfill its safety.

\section{REFERENCES}

Ashraf, W. (2005). Accumulation of heavy metals in kidney and heart tissues of Epinephelus microdon fish from the Arabian Gulf. Environ Monit Assess., 101: 311.

Agtas, Semsettin, Huseyin Gey and Suleyman Gul (2007). Concentrations of heavy metals in water and chub, Leuciscus cephalus (Linn.) from the river Yildiz, Turkey. J. Environ. Biol., 28: 845-849.

Deichmann, W. B., Mcdonald, D. A. and Cubit D. A., (1975). Dieldrine and DDT in the tissues of Labeo rohita (Ham.) following cadmium exposure. International Q uarterly J . Life Sci., $3(1): 23-25$.

Camargo, M.M. and Martinez, C.B. ( 2007). Histopathology of gills, kidney and liver of a Neotropical fish caged in an urban stream. Neotrop. I chthyol., 5: 327-336.

Dautremepuits, C., Paris-Palacios, S., Betoulle, S., Vernet, G. (2004). Modulation in hepatic and head kidney parameters of carp (Cyprinus carpio L .) induced by copper and chitosan. Comp Biochem Physiol C. Toxicol. Pharmacol., 137: 32533.

Fernandes, M.N. and Mazon, A.F. (2003). Environmental pollution and fish gill morphology. In: Val, A.L. and B.G. Kapoor (Eds.). Fish adaptation. Enfield. Science Publishers. pp: 203-231.

Gupta, Pallavi and Neera Srivastava (2006). Effects of sublethal concentrations of zinc on histological changes and bioaccumulation of zinc by kidney of fish, Channa punctatus (Bloch). J . Environ. Biol., 27: 211-215.

Kakuta, I. and Murachi, S. (1997).Physiological response of carp, Cyprinus carpio, exposed to raw sewage containing fish processing wastewater. Environ. Toxicol. Water Quality, 12: 1-9.

Kalay, M., Ay, P. and Canil, M. (1999). Heavy metal concentration in fish tissues from the northeast Mediterean sea. Bull Environ. Contam. Toxicol., 63 : 673- 671.

Olurin, K., Olojo, E., Mbaka G. and Akindele, A. (2006). Accumulation and Histopathological responses of the gill and liver tissues of Clarias gariepinus fingerlings to the herbicide, glyphosate. African J . Biotechnol., 5: 2480-2487.

Ortiz, J. B., M.L. Gonzale de Canales and Sarasquete, C. (2002). Histological alterations in different tissues of fishes under the impact of persistent chemical pollution. E cotoxicol. Environ. Restor., 54:45-52

Poleksic,V. and V. Mitrovic-Tutundzic (1994). Fish gills as a monitor of sublethal and chronic effects of pollution. In: Sublethal and chronic effects of pollutants on freshwater fish. Muller, R. and R. Lloyd (Eds.). Oxford, Fishing News Books, pp: 339-352.

Shukla, Vineeta, Monika Dhankhar, Jai Prakash and K.V. Sastry (2007). Bioaccumulation of $\mathrm{Zn}, \mathrm{Cu}$ and $\mathrm{Cd}$ in Channa punctatus. J. Enivron. Biol., 28 : 395-397.

Triebskorn, R., Telcean, I., Casper, H., Farkas, A., Sandu, C., Stan, G., Colarescu, O., Dori T. and Köhler, H. (2008). Monitoring pollution in River Mures, Romania, part II: Metal accumulation and histopathology in fish. Environ. Monit. Assess., 141: 177-188

Yoon, Seokjoo, Sang Seop Han and S.V.S. Rana (2008). Molecular markers of heavy metal toxicity - A new paradigm for health risk assessment. J. Environ. Biol., 29 : 1-14.

Wang, W. X. (2002). Interaction of trace metals and different marine food chains. Mar. E col. Prog. Ser., 243 : 295-309. 